\title{
Ukraine - en ny start?
}

\section{Anders Åslund}

\section{Ukrainsk politik oplever nu en lynhurtig spaltning af Orangerevolutionens top, efter at præsidenten har fyret sin premierminister og tidligere kamp- fælle. Der er god grund til at glæde sig over regeringsskiftet; men vælgernes dom er det svært at spå om}

Det har været et elendigt år for Ukraines økonomi. Sidste år oplevede Ukraine en økonomisk vækst på hele 12,1 procent; men den var faldet til 3,7 procent i de første syv måneder af 2005. For hver måned er produktionen blevet mindre. Industriproduktionen i juli var 2,4 procent lavere end i juli sidste år. Faldet i byggeaktiviteten og investeringerne er endnu større. Et enormt handelsoverskud sidste år er elimineret i løbet af de seneste måneder. Ukraine er øjensynlig på vej mod en vækst på 2-3 procent i 2005. Kun balancen på statens budget er positiv, fordi finansministeriet har ført en forsigtig finanspolitik.

Den økonomiske svækkelse skyldes landets egen $\varnothing$ konomiske politik. Det dominerende tema har været en omfattende diskussion om "genprivatisering". Premierminister Julia Tymosjenko talte på et tidspunkt om at 3.000 privatiseringer skulle revideres.

Et andet problem har været nødvendigheden af en brat stigning $\mathrm{i}$ skattebyrden på 5-6 procent af $\mathrm{BNP}$ for at finansiere meget store stigninger i overførselsindkomster og lønninger til offentligt ansatte.

Et tredje problem har været vidtrækkende regeringsindgreb i økonomien såsom forsøg på at regulere priserne på benzin, kød og korn og på at styrke visse statsmonopoler. En fordobling af taksterne for jernbanetransport af metal har også skadet $\varnothing$ konomien. Regeringen har opereret som et profitmaksimerende statsligt holdingselskab uden interesse for virkningerne på den private sektor. 


\section{Populisme uden reformer}

Samtidig var regeringen ikke gået i gang med nogen af de mange lovede og stærkt nødvendige liberale reformer. Det eneste positive skridt har været den sene vedtagelse af halvdelen af den WTO-relaterede lovgivning, som var nødvendig for Ukraines optagelse i WTO i år. Indtil nu er der ikke foretaget nogen deregulering i økonomien, selv om der har været talt meget om det. Ingen skatter er blevet sænket. Og der er ikke lovgivet for den finansielle sektor, skønt Ukraine end ikke har en aktieselskabslov.

Kort sagt har denne regering været en ren katastrofe af socialistisk populisme. Oven i alt dette har regeringen fulgt en linje med indædte offentlige angreb på individuelle forretningsfolk og politikere, heriblandt endog nogle af regeringens egne medlemmer. Otte måneder med dette rod var for meget.

Det var derfor en stor lettelse, da præsident Viktor Jusjtjenko satte sig igennem og gjorde en ende på dette offentlige ledelsessvigt. Meget fornuftigt kappede Jusjtjenko også forbindelsen til flere store forretningsfolk, som havde hjulpet med at finansiere og organisere hans kampagne, eftersom deres forhåbninger $\mathrm{om}$ at få økonomisk gevinst ud af deres positioner havde givet anledning til uro.

Med dette regeringsskifte ser vi afslutningen på Den Orange Revolu- tion. Julia Tymosjenko og hendes loyale støtter er nu sendt ud af regeringskontorerne, og Tymosjenko har erklæret, at hendes politiske blok vil være uafhængig af Jusjtjenkos. Spørgsmålet er nu, hvilken side de forskellige politikere og forretningsfolk vil vælge.

Én gammel oligark, Alexander Volkov, og den formentlig næststørste oligark-koncern, Privat Group i Dnipropetrovsk, har længe støttet Tymosjenko. Mere end tyve forretningsfolk i parlamentet har på det seneste sluttet sig til hendes partigruppe. Helt sensationelt får Tymosjenko pludselig støtte fra Kutjmas tidligere stabschef Viktor Medvedtjuk og hans Socialdemokratiske Parti - og stærk opbakning fra Ukraines første præsident, Leonid Kravtjuk.

Det ser mærkværdigt nok ud til, at Orangerevolutionens virkelige agitatorer og nogle af de mere misliebige oligarker er ved at finde sammen i Tymosjenkos blok.

\section{Præsidentens støtter}

Andre slutter sig til Jusjtjenko. Anatoly Kinakh og hans gruppe af liberale industrifolk er allerede med ham, og det synes parlamentsformanden Volodymyr Lytvyn også at være. Den hårdt pressede oligark Viktor Pintjuk og hans Labor Ukraine gruppe støtter ham allerede. Det formodes, at der i den nye regering bl.a. vil sidde en halv snes velrenom- 
merede tidligere Kutjma-ministre, som kan vinde støtte til Jusjtjenko fra fire-fem midtergrupper i parlamentet.

De store forretningsfolk, som hele vejen igennem har stået bag Jusjtjenko, især Petro Porosjenko, David Zhvania og Jevgeny Tjervonenko, forbliver loyale, selv om de forlader regeringen. Og tidligere præsident Leonid Kutjma har udtrykt støtte til Jusjtjenko. Jusjtjenkos gamle liberale vestligt orienterede eller moderat nationalistiske støtter vil sandsynligvis fortsat stå bag ham, og de midtsøgende oligark-grupper vil sandsynligvis slutte sig til ham.

Lidt mærkeligt er det, at Socialisterne er så ivrige for at bevare deres plads i regeringen, at de støtter Jusjtjenko, skønt de har været meget tættere på Tymosjenko.

Ironisk nok er det største udestående spørgsmål, hvor Donetskpartiet Regionerne med tidligere præsidentkandidat Viktor Janukovitj, som Orangerevolutionen fejede af banen, og Ukraines førende oligark, Rinat Akhmetov, vil gå hen. Akhmetov har længe set ud til at ville slutte fred med Jusjtjenko, men Janukovitj lyder som om han hælder til Tymosjenko.

Ukrainsk politik oplever nu en lynhurtig spaltning af Orangerevolutionens top, og de to ledere der står over for hinanden er Jusjtjenko og Tymosjenko, selv om de endnu ikke er gået til angreb på hinanden offentligt. Begge mobiliserer betydeli- ge styrker, som også omfatter store erhvervsfolk.

I bedste fald kunne man tænke sig, at der dannes et politisk landskab lidt i stil med det amerikanske med en slags Republikansk Parti omkring Jusjtjenko og et noget populistisk Demokratisk Parti omkring Tymosjenko, mens det lille Socialistparti og det endnu mindre Kommunistparti holder sig udenfor.

Mareridtet ville være en partipolitisk fragmentering som i Polen i 1990-1991.

\section{Jekhanurov får travlt}

I denne ophedede politiske situation er det svært at forestille sig en mere velegnet premierminister end Juri Jekhanurov. Som formand for Statens Ejendomsfond fra 1994 til 1997 gennemførte han masseprivatisering i Ukraine og skilte sig fra hvervet med stor hæder. Som 1. vicepremierminister under Jusjtjenko i 2000-2001 sørgede han for, at regeringen fungerede godt. Fra 2002 har han været en af lederne af Vort Ukraine i parlamentet, og som udvalgsformand har han fået skubbet betydningsfuld økonomisk lovgivning gennem parlamentet.

Trods mange år i politik har han stort set ingen fjender. Jekhanurov burde være i stand til både at holde sammen på Jusjtjenkos støtter og sætte regeringen i gang med arbejdet, skønt der skal være parlamentsvalg i marts 2006. 
Det er helt klart, hvad Jekhanurov skal i gang med. På meget kort tid skal han gennemføre en række ting. For det første er han stærkt opsat på at stoppe den hovedløse omprivatiseringskampagne. Privatiseringen af stålværket Krivorysjstal vil sandsynligvis blive gjort om, men intet andet. For det andet er der udkastet til en lovpakke, som skal afskaffe omkring 3.600 reguleringer. Det har været længe undervejs og er klar til at blive lagt frem i parlamentet.

For det tredje er den resterende WTO-lovgivning allerede i parlamentet; men Ukraine skal have den vedtaget og sat i kraft senest i løbet af oktober for at have en chance for at blive optaget $\mathrm{i}$ år.

For det fjerde er der den meget populistiske finanslov for næste år. Den indeholder ikke meget andet end sociale ydelser og offentlige lønninger, og den må laves om hurtigt. I særdeleshed er det nødvendigt at reducere de høje udgifter, og erhvervslivets sociale afgifter bør slås sammen og sænkes.
Og endelig vil Jekhanurov måske kunne få vedtaget den lovgivning for den finansielle sektor, som for længst er forberedt, men har ligget og ventet i parlamentet. Den økonomiske dagsorden kan omsider bliver relevant for Ukraines udvikling, og så vil den økonomiske vækst hurtigt kunne tage fart igen.

Der er al mulig grund til at glæde sig over regeringsskiftet i Ukraine og omstruktureringen af ukrainsk politik; men vælgernes dom er det svært at spå om.

Anders Åslund er direktør for Russian E Eurasian Program ved Washingtontanketanken Carnegie Endowment for International Peace. Klummen er skrevet den 12. september til Moskva-avisen "Vedomosti" og bringes her med forfatterens tilladelse.

Oversat fra engelsk af Klaus Carsten Pedersen. 